\title{
Development of Vaccination against Fungal Disease: A Review Article
}

\section{Gebrehiwet Tesfahuneygn * and Gebremichael Gebreegziabher}

Tigray Health Research Institute, Ethiopia

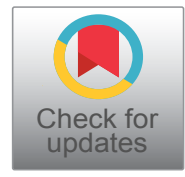

*Corresponding author: Gebrehiwet Tesfahuneygn, Tigray Health Research Institute, PO Box: 07, Ethiopia, Tel: +25134$2-414330$

\begin{abstract}
Vaccines have been hailed as one of the greatest achievements in the public health during the past century. So far, the development of safe and efficacious vaccines has been a major barrier for other infectious agents including fungi, partly due to of our lack of knowledge about the mechanisms that underpin protective immunity. Although fungi are responsible for pulmonary manifestations and cutaneous lesions in apparently immunocompetent individuals, their impact is most relevant in patients with severe immunocompromised, in which they can cause severe, life-threatening forms of infection. As an increasing number of immunocompromised individuals resulting from intensive chemotherapy regimens, bone marrow or solid organ transplantation, and autoimmune diseases have been witnessed in the last decades, so has the incidence of fungal diseases.

Vaccine development is a priority for several fungal pathogens, including $C$. albicans, C. neoformans, A. fumigatus, and dimorphic fungi. Many challenges confront vaccine development for fungi, including different host risk factors and modes of fungal pathogenesis. No single antigen can be expected to be used in a "pan-fungal" vaccine; rather, specific tailored vaccines will be required for the major fungal pathogens.

Immunotherapy can be evaluated as preventive or as adjunctive therapy. Prevention should be targeted to patients at significant risk for the infection of interest and should focus on infections with significant morbidity or mortality that are inadequately covered by standard therapies. One challenge relates to accrual of adequate numbers of patients in trials involving uncommon infections.
\end{abstract}

\section{Introduction}

Vaccines have been hailed as one of the greatest achievements in the public health during the past century. So far, the development of safe and efficacious vaccines has been a major barrier for other infectious agents including fungi, partly due to of our lack of knowledge about the mechanisms that underpin protective immunity.

Fungal diseases are epidemiological hallmarks of distinct settings of at risk patients; not only in terms of their underlying condition but in the spectrum of diseases they develop [1,2]. Although fungi are responsible for pulmonary manifestations and cutaneous lesions in apparently immunocompetent individuals, their impact is most relevant in patients with severe immune compromised, in which they can cause severe, life-threatening forms of infection. As an increasing number of immunocompromised individuals resulting from intensive chemotherapy regimens, bone marrow or solid organ transplantation, and autoimmune diseases have been witnessed in the last decades, so has the incidence of fungal diseases [1,2]. Regardless of hundreds of thousands of fungal species, only a few cause disease in humans. The most common fungi that infect humans are Candida spp., Aspergillus fumigatus, Cryptococcus neoformans, Pneumocystis jiroveci (carinii) and the thermally dimorphic fungi e.g. Histoplasma capsulatum, Blastomyces dermatitidis, Coccidioides posadasii, Penicillium marneffei and Paracoccidioides brasiliensis [3].

Despite recent additions to our antifungal drug armamentarium, success rates for many mycoses remain unacceptably low and antifungal drug therapy is often limited by toxicity, resistance and high cost. To circumvent these difficulties, alternative approaches to prevention and treatment are being developed, including vaccines and passive immunotherapy. 
Here, we review the progress of current research in this field, discuss some of the potential obstacles to developing and marketing a protective antifungal vaccine.

\section{Vaccines against the fungi}

In recent years, several studies in the field of medical mycology have been focused on the development of new vaccines against fungal pathogens. Many pertinent reviews and papers have been published with both new strategies and challenges to the development of antifungal vaccines due to the rise of dangerous systemic fungal infections, especially related to immunocompromised patients, premature infants, cancer patients and those with invasive treatments for long periods in hospital settings, which are known as high-risk groups [4-6]. High-risk groups in the past decades have been expanding in number owing to advances in the medical field, where new treatments to critical diseases, such as cancer, have arisen [7]. These treatments improve patient's survival rates, but can also affect natural barriers of the body or even significantly impact the competence of the immune system of the individual, contributing to an increased vulnerability to infections caused by fungi [8].

Vaccine development is a priority for several fungal pathogens, including C. albicans [9], C. neoformans [10], A. fumigatus [6], and dimorphic fungi [11]. Many challenges confront vaccine development for fungi, including different host risk factors and modes of fungal pathogenesis. No single antigen can be expected to be used in a "pan-fungal" vaccine; rather, specific tailored vaccines will be required for the major fungal pathogens [12].

One impediment to fungal vaccine development is that the patients who are most susceptible to opportunistic fungal infections are those least able to mount protective responses [13] showed that CD4+ T cells were dispensable in vaccine immunity against pulmonary blastomycosis (an extracellular pathogen) and histoplasmosis (a facultative intracellular pathogen) in immunocompromised mice. CD8+ T cells, in the absence of $\mathrm{CD} 4+\mathrm{T}$ cells, mediated vaccine-induced protection against these fungi, and protection by Blastomyces-immune CD8+ T cells could be adoptively transferred. These results contradict the dogma that induction of CD8+ $T$ cell responses against exogenously processed antigens requires $C D 4+T$ cells, and they provide encouragement for vaccine development for patients with impaired CD4+ T cell immunity (e.g., patients with advanced AIDS).

Another impediment relates to the limited number of licensed vaccine adjuvants. Candidate adjuvants that act on multiple innate and antigen-specific host defense pathways are likely to be the most effective in protecting against opportunistic fungal infections. The definition of adjuvants has mostly been restricted to those that stimulated antibody titers (e.g., pneumococcus) or in the case of the bacillus Calmette-Guerin vaccine, delayed-type hypersensitivity responses. More recently, the concept of adjuvants has been expanded to include soluble mediators and antigenic carriers (e.g., endotoxin, Flt3 ligand, and heat-shock protein) that activate antigen-presenting cells and stimulate innate and cellular immunity [14]. Heat-shock proteins are an example of naturally produced proteins that have been exploited as vaccine adjuvants in cancer and infectious diseases [1420]. Heat-shock proteins exhibit powerful immunostimulatory effects on dendritic cells in a TLR2- and TLR4-dependent fashion $[21,22]$ and induce antibody and type I cellular immunity that may be promising in fungal vaccine development [23]. Fungi also produce heat shock proteins that may be targets for vaccine development. Long, et al. [24] identified heat-shock protein 60 as the ligand on $\mathrm{H}$. capsulatum that mediates binding to CD18 receptors on human macrophages. Immunization with recombinant heat shock protein 60 from $H$. capsulatum conferred protection from a subsequent challenge in mice [25]. Paradoxically, vaccination may be useful to attenuate pathological inflammatory responses or induce tolerance. Allergic bronchopulmonary aspergillosis develops from sensitization to airway $A$. fumigatus antigens, leading to a Th2 CD4+ cell response characterized by secretion of IL-4, IL-5, and IL-13 [26]. T cells are the key components mediating allergic responses to A. fumigatus antigens in mouse models of allergic bronchopulmonary aspergillosis [27]. There is significant interest in immunotherapy for allergic bronchopulmonary aspergillosis, including the use of $\mathrm{CpG}$ sequences [28], recombinant allergens, and peptides to induce tolerance, as well as antigenic and DNA-based vaccines aimed at controlling the Th2-mediated responses in allergic bronchopulmonary aspergillosis [29].

\section{Challenges in Designing Mycological Immuno- therapy Trials}

Immunotherapy can be evaluated as preventive or as adjunctive therapy. Prevention should be targeted to patients at significant risk for the infection of interest and should focus on infections with significant morbidity or mortality that are inadequately covered by standard therapies.

One challenge relates to accrual of adequate numbers of patients in trials involving uncommon infections. Assuming a vaccine with $80 \%$ efficacy in preventing invasive aspergillosis and a $5 \%$ frequency of invasive aspergillosis in a population of interest (e.g., allogeneic hematopoietic stem cell transplant recipients), subjects receiving the vaccine would be expected to have a $1 \%$ rate of invasive aspergillosis. Assuming a power of 0.8, a ! .05, and a 1-sided analysis designed to show superiority of vaccination, a sample size of 544 patients would be required. This number is, in fact, an underestimate, because it does not consider false-positive diagnoses 
or differences in antifungal prophylaxis and diagnostic evaluation between centers, which would reduce the ability of the analysis to detect a protective effect of vaccination. Selecting a patient population with a higher risk of invasive aspergillosis (e.g., T cell-depleted allogeneic hematopoietic stem cell transplant recipients) would reduce the required sample size. The paradigm for clinical trial design aimed at preventing infection with dimorphic fungi (e.g., by vaccination) will be different, because these pathogens affect both immunocompetent and immunocompromised persons and are geographically restricted. In the 1980s, a randomized placebo-controlled study involving 2867 subjects from regions of endemicity showed no benefit of the formalin-killed spherule vaccine in preventing coccidioidomycosis [30]. The frequency of definite coccidioidomycosis was $\sim 1 \%$, emphasizing the need for large numbers of subjects to demonstrate vaccine efficacy. Additional candidate vaccines for coccidioidomycosis are being developed [31]. Studies of adjunctive immunotherapy for established infection should target specific well-defined patient groups to maximize the likelihood of detecting a treatment effect. Kullberg, et al. [32] reasonably suggest that phase I and II studies of immunotherapies should focus on laboratory surrogates that are likely to predict efficacy (e.g., augmenting Th1 responses), which would pave the way to larger studies that evaluate clinically relevant end points (e.g., survival and resolution of infection). Funding for clinical trials of novel antifungal therapeutics may be the most important hurdle. Vaccines targeted to pathogens that affect a broad segment of the general population have more attractive marketing potential than do vaccines for opportunistic fungal pathogens that affect only those individuals with severe defects in the immune system. Bringing promising, novel antifungal immunotherapeutic to clinical trials and to market will likely require creative partnerships between academia, industry, and government.

\section{Immune response against fungal infections}

For all pathogens discussed in this review an interconnected innate and adaptive immune response is necessary for the resolution of the infection [6].

Innate response-The innate response against fungi is designed to be as efficient as possible and also stimulates several responses mediated by the adaptive immune system [33]. The first lines of defense are physical barriers, like the skin and mucosal epithelial surfaces in the sites of the body that are constantly being exposed to environmental organisms, including sites such as the mouth, the upper airways and the gastrointestinal and genitourinary tract [34]. The epithelium also has an important role by actively discriminating commensal fungi, such as $C$. albicans, which occurs in a nonpathogenic and pathogenic form [35].

Adaptive response-After stimulation of the innate immune system, it is essential that T-cells are activated for a successful elimination and development of protective immunity against fungi [36]. Hence, the majority of invasive fungal infections occur in condition of T-cell deficiency. The specific cytokines expressed by APCs cells like DCs and macrophages are crucial for the differentiation of CD4+ T-cells (T-helper cells) [37-39].

Since the kingdom Fungi besets a heterogeneous group of organisms, it is expected that each one will elicit a different immunological response (Table 1).

Table 1: Type of vaccines for fungal disease and their mechanisms of protection.

\begin{tabular}{|c|c|c|c|c|}
\hline $\begin{array}{l}\text { Type of vaccines } \\
\text { of }\end{array}$ & Fungal diseases & Antigens & Mechanism(s) of protection & Reference \\
\hline \multirow{13}{*}{$\begin{array}{l}\text { Whole Cells and } \\
\text { Cell Extracts }\end{array}$} & \multirow{5}{*}{ Candidiasis } & Strain CA2, live-attenuated & T-helper 1 , cell-mediated immunity & {$[40,41]$} \\
\hline & & $\begin{array}{l}\text { Genetically engineered } \\
\text { Candida albicans tet-NRG1 } \\
\text { strain, live-attenuated }\end{array}$ & T-cell mediated immunity & [42] \\
\hline & & Ribosomal Cell fraction & Antibodies and cell-mediated immunity & {$[43,44]$} \\
\hline & & Inactivated whole cells & Undefined & [45] \\
\hline & & Hyr1p & Cell mediated immunity & [46] \\
\hline & \multirow{5}{*}{$\begin{array}{l}\text { Blastomycosis } \\
\text { Coccidioidomycosis }\end{array}$} & Strain BAD1, live-attenuated & T-helper 1 , cell-mediated immunity & [47] \\
\hline & & Inactivated spherules & T-helper 1 , cell-mediated immunity & {$[31,48]$} \\
\hline & & $\begin{array}{l}\text { Thimerosal-inactivated } \\
\text { spherules (T27K) }\end{array}$ & Undefined & [49] \\
\hline & & $\begin{array}{l}\text { Genetically engineered strain, } \\
\text { live-attenuated }\end{array}$ & $\begin{array}{l}\text { T-helper } 1 \text {, T-helper } 2 \text {, cell-mediated } \\
\text { immunity }\end{array}$ & {$[50]$} \\
\hline & & $\begin{array}{l}\text { Heat-killed Saccharomyces } \\
\text { cerevisiae (HKY) }\end{array}$ & Undefined & [51] \\
\hline & \multirow[t]{2}{*}{ Aspergillosis } & Inactivated Conidia & Undefined & [52] \\
\hline & & Live attenuated conidia & Undefined & [53] \\
\hline & Histoplasmosis & Ribosomal Vaccine & Undefined & [54] \\
\hline
\end{tabular}




\begin{tabular}{|c|c|c|c|c|}
\hline \multirow[t]{4}{*}{ DNA } & Coccidioidomycosis & More than one gene & Undefined & [55] \\
\hline & \multirow[t]{2}{*}{ Para coccidioidomycosis } & gp43 gene & $\begin{array}{l}\text { T-helper } 1 \text {, T-helper } 2 \text {, cell-mediated } \\
\text { immunity }\end{array}$ & [56] \\
\hline & & HSP65 DNA & T-helper 1 & [57] \\
\hline & Pneumocystis & Kexin gene & Cell-mediated immunity and antibodies & [58] \\
\hline \multirow{4}{*}{$\begin{array}{l}\text { Antigen-pulsed } \\
\text { cells and T } \\
\text { cells }\end{array}$} & Candidiasis & $\begin{array}{l}\text { Dendritic cell loaded with } \\
\text { candida antigens }\end{array}$ & T-helper 1 , cell-mediated immunity & {$[50,59,60]$} \\
\hline & Aspergillus & Dendritic cell loaded with & T-helper 1, cell-mediated immunity & {$[50,59,61]$} \\
\hline & Antigen-specific T cells & candida antigens & & \\
\hline & Coccidioidomycosis & Dendritic cell based vaccine & Undefined & [62] \\
\hline \multirow{18}{*}{$\begin{array}{l}\text { Subunit and } \\
\text { Glycoconjugates }\end{array}$} & \multirow[t]{7}{*}{ Candidiasis } & Agglutinin-like sequences & Cell-mediated immunity & [63] \\
\hline & & ecm33 mutant (RML2U) & Undefined & {$[64,65]$} \\
\hline & & Secreted aspartic proteinase 2 & Anti-Sap2 antibodies & [66] \\
\hline & & 65 kDa mannoprotein & Adhesin-neutralizing antibodies & [67] \\
\hline & & Beta-1,3-glucan & Cell-mediated immunity & {$[68,69]$} \\
\hline & & Beta-1,2-mannosides & $\begin{array}{l}\text { Antibodies(opsonophagocytic; possibly } \\
\text { adherence-blocking) }\end{array}$ & {$[70,71]$} \\
\hline & & CR3-RP glycoconjugate & Cell-mediated immunity & [72] \\
\hline & \multirow[t]{2}{*}{ Cryptococcosis } & Capsular polysaccharides & Various mechanisms & [73] \\
\hline & & $\begin{array}{l}\text { Glucuronoxylomannan- } \\
\text { conjugated vaccine }\end{array}$ & Unknown, possibly antibodies & [73] \\
\hline & \multirow[t]{2}{*}{ Aspergillosis } & Aspergillus fumigatus antigens & Cell-mediated immunity & {$[12,49]$} \\
\hline & & Beta-1,3-glucan & Growth inhibitors, antibodies & [74] \\
\hline & \multirow[t]{3}{*}{ Coccidioidomycosis } & Antigen2 & Cell-mediated immunity, T-helper 1 & [75] \\
\hline & & Beta-1,3-glucosyltransferases & Undefined & [57] \\
\hline & & Chimeric polyprotein & Undefined & {$[31,76]$} \\
\hline & \multirow[t]{2}{*}{ Pneumocystis } & $\begin{array}{l}\text { P55 protein (major surface } \\
\text { glycoprotein) }\end{array}$ & Undefined, possibly antibodies & [77] \\
\hline & & Kexin protease & Cell-mediated immunity and antibodies & [57] \\
\hline & \multirow[t]{2}{*}{ Para coccidioidomycosis } & 43 kDa glycoprotein & Cell-mediated immunity and antibodies & [55] \\
\hline & & HSP60 & Cell-mediated immunity & [78] \\
\hline \multirow[t]{4}{*}{$\begin{array}{l}\text { Idiotypes and } \\
\text { mimotopes }\end{array}$} & Candidiasis & $\begin{array}{l}\text { Killer toxin neutralizing } \\
\text { mAbKT4 }\end{array}$ & Fungicidal antibodies & [77-79] \\
\hline & Aspergillosis & $\begin{array}{l}\text { Killer toxin neutralizing } \\
\text { mAbKT4 }\end{array}$ & Fungicidal antibodies & {$[80]$} \\
\hline & \multirow[t]{2}{*}{ Cryptococcosis } & $\begin{array}{l}\text { Glucuronoxylomannan- } \\
\text { peptide mimotopes }\end{array}$ & $\begin{array}{l}\text { Antibodies modulating cell-mediated } \\
\text { immunity }\end{array}$ & [81] \\
\hline & & $\begin{array}{l}\text { P13 peptide mimotope-protein } \\
\text { conjugates }\end{array}$ & $\begin{array}{l}\text { T-helper } 1 \text {, T-helper } 2 \text {, cell-mediated } \\
\text { immunity }\end{array}$ & [82] \\
\hline \multirow[t]{12}{*}{ Antibodies } & \multirow[t]{8}{*}{ Candidiasis } & Mycograb, anti-Hsp90 peptide & Unknown & {$[83,84]$} \\
\hline & & Anti-CA lgY & Inhibition of adhesion to host cells & [85] \\
\hline & & Anti-beta-1,3-glucan mAb 2G8 & Growth-inhibitory & {$[67,68]$} \\
\hline & & $\begin{array}{l}\text { mAb C7 (stress } \\
\text { mannoprotein) }\end{array}$ & Candidacidal & [86] \\
\hline & & $\begin{array}{l}\text { Single chain fragment variable } \\
\text { of anti-idiotypic antibodies }\end{array}$ & Candidacidal antibodies & {$[80]$} \\
\hline & & Anti-mannan mAb C6 & Opsonophagocytic & {$[79,80]$} \\
\hline & & Anti-glycosyl mAb & Candidacidal & [87] \\
\hline & & $\begin{array}{l}\text { Anti-Sap2 and anti- } \\
\text { MP65domain antibodies }\end{array}$ & Enzyme and adhesion neutralizing & [88] \\
\hline & \multirow[t]{3}{*}{ Cryptococcosis } & Single chain fragment variable & Inhibits glucan synthase & [89] \\
\hline & & $\begin{array}{l}\text { Anti-glucuronoxylomannan } \\
\text { 18B7-mAb (murine) }\end{array}$ & Opsonophagocytic & [90] \\
\hline & & $\begin{array}{l}\text { Anti-glucuronoxylomannan } \\
\text { IgG2-mAb (human) }\end{array}$ & Opsonophagocytic & [91] \\
\hline & Histoplasmosis & $\begin{array}{l}\text { Antibody against histone-like } \\
\text { protein }\end{array}$ & Undefined & [92] \\
\hline
\end{tabular}




\begin{tabular}{|c|c|c|c|c|}
\hline \multirow[t]{4}{*}{$\begin{array}{l}\text { Synthetic, } \\
\text { recombinant } \\
\text { and conjugate } \\
\text { vaccines }\end{array}$} & Candidiasis & $\begin{array}{l}\text { beta-(Man)(3)-Fba,beta- } \\
\text { (Man)(3)-Met6,beta-(Man) } \\
\text { (3)-Hwp1, beta-(Man) } \\
\text { (3)-Eno1, beta-(Man) } \\
\text { (3)-Gap1, beta-(Man)(3)-Pgk1 }\end{array}$ & Unknown & [93] \\
\hline & Coccidioidomycosis & $\begin{array}{l}\text { Recombinant Ag2/PRA106 + } \\
\text { CSA chimeric fusion protein } \\
\text { (CFP) vaccine }\end{array}$ & Cell-mediated immunity & [94] \\
\hline & & $\begin{array}{l}\text { Recombinant proline-rich } \\
\text { antigen (rAg2/Pra) }\end{array}$ & T cell-mediated immunity & [95] \\
\hline & Para coccidioidomycosis & Antigenic protein (rPb27) & Cell-mediated immunity and antibodies & [96] \\
\hline
\end{tabular}

\section{Competing Interests}

The authors declare that they have no competing interests.

\section{Authors' Contribution}

GT, GG wrote and edited the manuscript. All authors read and approved the final manuscript.

\section{References}

1. Segal BH (2009) Aspergillosis. N Engl J Med 360: 18701884.

2. Shubitz LF, Yu JJ, Hung CY, Kirkland TN, Peng T, et al. (2006) Improved protection of mice against lethal respiratory infection with coccidioides posadasii using two recombinant antigens expressed as a single protein. Vaccine 24 : 5904-5911.

3. Pfaller MA, Diekema DJ (2010) Epidemiology of invasive mycoses in North America. Crit Rev Microbiol 36: 1-53.

4. Spellberg B (2011) Vaccines for invasive fungal infections. F1000 Med Rep 3: 13.

5. Iannitti RG, Carvalho A, Romani L (2012) From memory to antifungal vaccine design. Trends Immunol 33: 467-474.

6. Roy RM, Klein BS (2012) Dendritic cells in anti-fungal immunity and vaccine design. Cell Host Microbe 11: 436-446.

7. Das R, Ranganathan R (2012) An overview of changing trends in systemic fungal infections. WebmedCentral 3.

8. Paramythiotou E, Frantzeskaki F, Flevari A, Armaganidis A, Dimopoulos G (2014) Invasive fungal infection in the ICU: How to approach, how to treat. Molecules 19: 1085-1119.

9. Ibrahim AS, Spellberg BJ, Avenissian V, Fu Y, Filler SG, et al. (2005) Vaccination with recombinant N-terminal domain of Als1p improves survival during murine disseminated candidiasis by enhancing cell-mediated, not humoral, immunity. Infect Immun 73: 999-1005.

10. Perfect JR, Casadevall A (2002) Cryptococcosis. Infect Dis Clin North Am 16: 837-874.

11. Stevens DA (2004) Vaccinate against aspergillosis! A call to arms of the immune system. Clin Infect Dis 38: 11311136.

12. Cox RA, Magee DM (2004) Coccidioidomycosis: Host response and vaccine development. Clin Microbiol Rev 17: 804-839.

13. Deepe GS Jr (2004) Preventative and therapeutic vaccines for fungal infections: From concept to implementation. Expert Rev Vaccines 3: 701-709.

14. Wuthrich M, Filutowicz HI, Warner T, Deepe GS Jr, Klein BS (2003) Vaccine immunity to pathogenic fungi overcomes the requirement for CD4 help in exogenous anti- gen presentation to CD8+ T cells: Implications for vaccine development in immune-deficient hosts. J Exp Med 197: 1405-1416.

15. Gamvrellis A, Leong D, Hanley JC, Xiang SD, Mottram P, et al. (2004) Vaccines that facilitate antigen entry into dendritic cells. Immunol Cell Biol 82: 506-516.

16. Wang XY, Li Y, Manjili MH, Repasky EA, Pardoll DM, et al. (2002) Hsp110 over-expression increases the immunogenicity of the murine CT26 colon tumor. Cancer Immunol Immunother 51: 311-319.

17. Manjili $M H$, Henderson $R$, Wang $X Y$, Chen $X$, Li $Y$, et al. (2002) Development of a recombinant HSP110-HER-2/neu vaccine using the chaperoning properties of HSP110. Cancer Res 62: 1737-1742.

18. Manjili MH, Wang XY, Park J, Facciponte JG, Repasky EA, et al. (2002) Immunotherapy of cancer using heat shock proteins. Front Biosci 7: 43-52.

19. Wang $X Y$, Chen $X$, Manjili MH, Repasky E, Henderson R, et al. (2003) Targeted immunotherapy using reconstituted chaperone complexes of heat shock protein 110 and melanoma-associated antigen gp100. Cancer Res 63: 25532560.

20. Manjili MH, Wang XY, Chen X, Martin T, Repasky EA, et al. (2003) HSP110-Her-2/neu chaperone complex vaccine induces protective immunity against spontaneous mammary tumors in HER-2/neu transgenic mice. J Immunol 171: 4054-4061.

21. Srivastava $P$ (2002) Roles of heat-shock proteins in innate and adaptive immunity. Nat Rev Immunol 2: 185-194.

22. Vabulas RM, Ahmad-Nejad P, Ghose S, Kirschning CJ, Issels RD, et al. (2002) HSP70 as endogenous stimulus of the Toll/interleukin-1 receptor signal pathway. J Biol Chem 277: 15107-15112.

23. Asea A, Rehli M, Kabingu E, Boch JA, Bare O, et al. (2002) Novel signal transduction pathway utilized by extracellular HSP70: Role of toll-like receptor (TLR) 2 and TLR4. J Biol Chem 277: 15028-15034.

24. Segal B, Dennis C, Subjeck J, Sands M, Kurup V, et al. (2005) Heat shock protein 110/Aspergillus antigen (Asp f2) complex activates dendritic cells in vitro in a toll like receptor (TLR) 4-dependent fashion and stimulates type 1 cytokine-mediated antigen-specific antibody responses in mice. In: $15^{\text {th }}$ Focus on Fungal Infections, Miami.

25. Long KH, Gomez FJ, Morris RE, Newman SL (2003) Identification of heat shock protein 60 as the ligand on Histoplasma capsulatum that mediates binding to CD18 receptors on human macrophages. J Immunol 170: 487-494.

26. Scheckelhoff M, Deepe GS Jr (2002) The protective immune response to heat shock protein 60 of histoplasma capsulatum is mediated by a subset of $\mathrm{V}$ beta $8.1 / 8.2+\mathrm{T}$ cells. J Immunol 169: 5818-5826. 
27. Stevens DA, Moss RB, Kurup VP, Knutsen AP, Greenberger $\mathrm{P}$, et al. (2003) Allergic bronchopulmonary aspergillosis in cystic fibrosis--state of the art: Cystic Fibrosis Foundation Consensus Conference. Clin Infect Dis 37: S225-S264.

28. Corry DB, Grunig G, Hadeiba H, VP Kurup, ML Warnock, et al. (1998) Requirements for allergen-induced airway hyperreactivity in T and B cell-deficient mice. Mol Med 4: 344355.

29. Banerjee B, Kelly KJ, Fink JN, Henderson JD Jr, Bansal NK, et al. (2004) Modulation of airway inflammation by immunostimulatory CpG oligodeoxynucleotides in a murine model of allergic aspergillosis. Infect Immun 72: 6087-6094.

30. Svirshchevskaya EV, Kurup VP (2003) Immunotherapy of allergic bronchopulmonary aspergillosis: A clinical and experimental approach. Front Biosci 8: s92-s101.

31. Pappagianis D (1993) Evaluation of the protective efficacy of the killed coccidiodes immitis spherule vaccine in humans. The Valley Fever Vaccine Study Group. Am Rev Respir Dis 148: 656-660.

32. Kullberg BJ, Oude Lashof AM, Netea MG (2004) Design of efficacy trials of cytokines in combination with antifungal drugs. Clin Infect Dis 39: S218-S223.

33. Santamaria R, Rizzetto L, Bromley M, Zelante T, Lee W, et al. (2011) Systems biology of infectious diseases: A focus on fungal infections. Immunobiology 216: 1212-1217.

34. Borghi M, Renga G, Puccetti M, Oikonomou V, Palmieri M, et al. (2014) Antifungal Th immunity: Growing up in family. Front Immunol 5: 506.

35. Cutler JE, Deepe Jr GS, Klein BS (2007) Advances in combating fungal diseases: Vaccines on the threshold. Nat Rev Microbiol 5: 13-28.

36. Hamad M (2011) Innate and adaptive antifungal immune responses: Partners on an equal footing. Mycosis 55: 205217.

37. LeidbundGut-Landmann S, Wüthrich M, Hohl TM (2012) Immunity to fungi. Curr Opin Immunol 24: 449-458.

38. Rohatgi S, Pirofski LA (2015) Host immunity to cryptococcus neoformans. Future Microbiol 10: 565-581.

39. Bozza S, Montagnoli C, Gaziano R, Rossi G, Nkwanyuo G, et al. (2004) Dendritic cell-based vaccination against opportunistic fungi. Vaccine 22: 857-864.

40. Bistoni F, Vecchiarelli $A$, Cenci E, Puccetti $P$, Marconi $P$, et al. (1986) Evidence for macrophage-mediated protection against lethal Candida albicans infection. Infect Immun 51: 668-674.

41. Saville SP, Lazzell AL, Chaturvedi AK, Monteagudo C, Lopez-Ribot JL (2009) Efficacy of a genetically engineered candida albicans tet-NRG1 strain as an experimental live attenuated vaccine against hematogenously disseminated candidiasis. Clin Vaccine Immunol 16: 430-432.

42. Segal E, Elad D (2006) Fungal vaccines and immunotherapy. J Mycolog Med 16: 134-151.

43. Levy DA, Bohbot JM, Catalan F, Normier G, Pinel AM, et al. (1989) Phase II study of D.651, an oral vaccine designed to prevent recurrences of vulvovaginal candidiasis. Vaccine 7: $337-340$.

44. Cardenas-Freitag L, Cheng E, Mayeux P, Domer JE, Clemens JD (1999) Effectiveness of a vaccine composed of heat-killed candida albicans and a novel mucosal adjuvant, LT(R192G), against systemic candidiasis. Infect Immun 67: 826-833.
45. Luo G, Ibrahim AS, Spellberg B, Nobile CJ, Mitchell AP, et al. Candida albicans Hyr1p confers resistance to neutrophil killing and is a potential vaccine target. J Infect Dis 201: 1718-1728.

46. Wuthrich M, Chang WL, Klein BS (1998) Immunogenicity and protective efficacy of the WI-1 adhesin of Blastomyces dermatitidis. Infect Immun 66: 5443-5449.

47. Cole GT, Xue JM, Okee CN, Tarcha EJ, Basrur V, et al. (2004) A vaccine against coccidioidomycosis is justified and attainable. Med Mycol 42: 189-216.

48. Lunetta JM, Simmons KA, Johnson SM, Pappagianis D (2007) Molecular cloning and expression of a cDNA encoding a coccidioides posadasii 1,2-alpha-mannosidase identified in the coccidioidal T27K vaccine by immunoproteomic methods. Ann N Y Acad Sci 1111: 164-180.

49. Xue J, Chen X, Selby D, Hung CY, Yu JJ, et al. (2009) A genetically engineered live attenuated vaccine of coccidioides posadasii protects BALB/c mice against coccidioidomycosis. Infect Immun 77: 3196-3208.

50. Capilla J, Clemons KV, Liu M, Levine HB, Stevens DA (2009) Saccharomyces cerevisiae as a vaccine against coccidioidomycosis. Vaccine 27: 3662-3668.

51. Feldmesser M (2005) Prospects of vaccines for invasive aspergillosis. Med Mycol 43: 571-587.

52. Deepe GS Jr, Wuthrich M, Klein BS (2005) Progress in vaccination for histoplasmosis and blastomycosis: Coping with cellular immunity. Med Mycol 43: 381-389.

53. Ivey FD, Magee DM, Woitaske MD, Johnston SA, Cox RA (2003) Identification of protective antigen of coccidioides immitis by expression library immunization. Vaccine 21 : 4359-4367.

54. Pinto AR, Puccia R, Diniz SR, Franco MF, Travassos LR (2000) DNA-based vaccination against murine paracoccidioidomycosis using the gp43 gene from Paracoccidioides brasiliensis. Vaccine 18: 3050-3058.

55. Ribeiro AM, Bocca AL, Amaral AC, Souza AC, Faccioli LH, et al. (2010) HSP65 DNA as therapeutic strategy to treat experimental paracoccidioidomycosis. Vaccine 28: 1528-1534.

56. Zheng M, Ramsay AJ, Robichaux MB, Kliment C, Crowe C, et al. (2005) CD4+ T cell-independent DNA vaccination against opportunistic infections. J Clin Invest 115: 3536-3544.

57. Perruccio K, Bozza S, Montagnoli C, Bellocchio S, Aversa F, et al. (2004) Prospects for dendritic cell vaccination against fungal infections in hematopoietic transplantation. Blood Cells Mol Dis 33: 248-255.

58. Bacci A, Montagnoli C, Perruccio K, Bozza S, Gaziano R, et al. (2002) Dendritic cells pulsed with fungal RNA induce protective immunity to Candida albicans in hematopoietic transplantation. J Immunol 168: 2904-2913.

59. Cenci E, Mencacci A, Bacci A, Bistoni F, Kurup VP, et al. (2000) T cell vaccination in mice with invasive pulmonary aspergillosis. J Immunol 165: 381-388.

60. Awasthi S (2007) Dendritic cell-based vaccine against coccidioides infection. Ann N Y Acad Sci 1111: 269-274.

61. Ibrahim AS, Spellberg BJ, Avanesian V, Fu Y, Edwards JE $\mathrm{Jr}$ (2006) The anti-candida vaccine based on recombinant $\mathrm{N}$-terminal domain of Als $1 \mathrm{p}$ is broadly active against disseminated candidiasis. Infect Immun 74: 3039-3041.

62. Spellberg BJ, Ibrahim AS, Avanesian V, Fu Y, Myers C, et al. (2006) Efficacy of the anti-candida rAls3p-N or Als1p-N vaccines against disseminated and mucosal candidiasis. $J$ Infect Dis 194: 256-260. 
63. Martínez-López R, Nombela C, Diez-Orejas R, Monteoliva $\mathrm{L}$, Gil C (2008) Immunoproteomic analysis of the protective response obtained from vaccination with Candida albicans ecm33 cell wall mutant in mice. Proteomics 8: 2651-2664.

64. Cassone A, Boccanera M, Adriani D, Dantoni G, De Bernardis $F(1995)$ Rats clearing a vaginal infection by candida albicans acquire specific, antibody-mediated resistance to vaginal reinfection. Infect Immun 63: 2619-2624.

65. Sandini S, La Valle R, De Bernardis F, Macrì C, Cassone A (2007) The 65 kDa mannoprotein gene of Candida albicans encodes a putative beta-glucanase adhesin required for hyphal morphogenesis and experimental pathogenicity. Cell Microbiol 9: 1223-1238.

66. Torosantucci A, Bromuro C, Chiani P, Flavia De Bernardis, Francesco Berti, et al. (2005) A novel glyco-conjugate vaccine against fungal pathogens. J Exp Med 202: 597-606.

67. Cassone A, Torosantucci A (2006) Opportunistic fungi and fungal infections: The challenge of a single, general antifungal vaccine. Expert Rev Vaccines 5: 859-867.

68. Cutler JE (2005) Defining criteria for anti-mannan antibodies to protect against candidiasis. Curr Mol Med 5: 383-392.

69. Han Y, Ulrich MA, Cutler JE (1999) Candida albicans mannan extract-protein conjugates induce a protective immune response against experimental candidiasis. J Infect Dis 179: $1477-1484$.

70. Paulovicová E, Bystrický S, Machová E, Bujdáková H (2008) Immune responsiveness of a novel peptidoglycan conjugate prepared from surface Candida immunogens: Mannan and CR3-related protein. FEMS Immunol Med Microbiol 53: 421-428.

71. Oscarson S, Alpe M, Svahnberg P, Nakouzi A, Casadevall A (2005) Synthesis and immunological studies of glycoconjugates of cryptococcus neoformans capsular glucuronoxylomannan oligosaccharide structures. Vaccine 23: 3961-3972.

72. Ito JI, Lyons JM, Hong TB, Daniel Tamae, Yi-Kuang Liu, et al. (2006) Vaccinations with recombinant variants of Aspergillus fumigatus allergen Asp f 3 protect mice against invasive aspergillosis. Infect Immun 74: 5075-5084.

73. Luther K, Torosantucci A, Brakhage AA, Heeseman J, Ebel F (2007) Phagocytosis of Aspergillus fumigatus conidia by murine macrophages involves recognition by dectin-1 beta-glucan receptor and Toll-like receptor 2. Cell Microbiol 9: 368-381.

74. Tarcha EJ, Basrur V, Hung CY, Gardner M, Cole GT (2006) A recombinant aspartyl protease of coccidioides posadasii induces protection against pulmonary coccidioidomycosis in mice. Infect Immun 74: 516-517.

75. Theus SA, Smulian AG, Steele P, Linke MJ, Walzer PD (1998) Immunization with the major surface glycoprotein of Pneumocystis carinii elicits a protective response. Vaccine 16: 1149-1157.

76. De Bastos Ascenço Soares R, Gomez FJ, de Almeida Soares CM, Deepe GS Jr (2008) Vaccination with heat shock protein 60 induces a protective immune response against experimental paracoccidioides brasiliensis pulmonary infection. Infect Immun 76: 4214-4221.

77. Polonelli L, Lorenzini R, De Bernardis F, Gerloni M, Conti $S$, et al. (1993) Idiotypic vaccination: Immunoprotection mediated by anti-idiotypic antibodies with antibiotic activity. Scand J Immunol 37: 105-110.

78. Polonelli L, De Bernardis F, Conti S, Boccanera M, Gerloni $\mathrm{M}$, et al. (1994) Idiotypic intravaginal vaccination to protect against candidal vaginitis by secretory yeast killer toxin-like anti-idiotype antibodies. J Immunol 152: 3175-3182.

79. Magliani W, Conti S, Salati A, Arseni S, Ravanetti L, et al. (2004) Engineered killer mimotopes: New synthetic peptides for antimicrobial therapy. Curr Med Chem 11: 17931800.

80. Datta K, Pirofski LA (2006) Towards a vaccine for cryptococcus neoformans: Principles and caveats. FEMS Yeast Res 6: 525-536.

81. Maitta RW, Datta K, Lees A, Belouski SS, Pirofski LA (2004) Immunogenicity and efficacy of cryptococcus neoformans capsular polysaccharide glucuronoxylomannan peptide mimotope-protein conjugates in human immunoglobulin transgenic mice. Infect Immun 72: 196-208.

82. Matthews RC, Rigg G, Hodgetts S, Carter T, Chapman C, et al. (2003) Preclinical assessment of the efficacy of mycograb, a human recombinant antibody against fungal HSP90. Antimicrob Agents Chemother 47: 2208-2216.

83. Pachl J, Svoboda P, Jacobs F, Vandewoude K, van der Hoven B, et al. (2006) A randomized, blinded, multicenter trial of lipid-associated amphotericin $B$ alone versus in combination with an antibody-based inhibitor of heat-shock protein 90 in patients with invasive candidiasis. Clin Infect Dis 42: 1404-1413.

84. Cassone A, Conti S, De Bernardis F, Polonelli L (1997) Antibodies, killer toxins and antifungal immunoprotection: A lesson from nature? Immunol Today 18: 164-169.

85. Ibrahim el-SM, Rahman AK, Isoda R, Umeda K, Van Sa N, et al. (2008) In vitro and in vivo effectiveness of egg yolk antibody against candida albicans (anti-CA IgY). Vaccine 26: 2073-2080.

86. Moragues MD, Omaxtebarria MJ, Natalia Elguezabal, María J Sevilla, Stefania Conti, et al. (2003) A monoclonal antibody directed against Candida albicans cell wall mannoprotein exerts three anti-C. albicans activities. Infect Immun 71: 5273-5279.

87. Kawishwar A, Shukla PK (2006) Candidacidal activity of a monoclonal antibody that binds with glycosyl moieties of proteins of candida albicans. Med Mycol 44: 159-167.

88. De Bernardis F, Liu H, O'Mahony R, La Valle R, Bartollino $S$, et al. (2006) Human domain antibodies against virulence traits of candida albicans inhibit fungus adherence to vaginal epithelium and protect against experimental vaginal candidiasis. J Infect Dis 195: 149-157.

89. Selvakumar D, Karim N, Miyamoto M, Furuichi Y, Komiyama T (2006) Recombinant single chain anti-idiotypic antibody: An effective fungal beta-1,3-glucan synthase inhibitor. Biol Pharm Bull 29: 1848-1853.

90. Larsen RA, Pappas PG, Perfect J, Aberg JA, Casadevall A, et al. (2005) Phase 1 evaluation of safety and pharmacokinetics of murine-derived anticryptococcal antibody 18B7 in subjects with treated cryptococcal meningitis. Antimicrob Agents Chemother 49: 952-958.

91. Beenhover DO, Yoo EM, Lai CW, Rocha MA, Morrison SL (2007) Human immunoglobulin G2 (IgG2) and IgG4 but not IgG1 or IgG3, protect mice against cryptococcus neoformans infection. Infect Immun 75: 1424-1435.

92. Nosanchuk JD, Steenbergen JN, Shi L, Deepe GS, Casadevall A (2003) Antibodies to a cell surface histone-like protein protect against Histoplasma capsulatum. J Clin Invest 112: 1164-1175.

93. Xin H, Dziadek S, Bundle DR, Cutler JE (2008) Synthetic 
glycopeptide vaccines combining beta-mannan and peptide epitopes induce protection against candidiasis. Proc Natl Acad Sci U S A 105: 13526-13531.

94. Johnson SM, Lerche NW, Pappagianis D, Yee JL, Galgiani JN, et al. (2007) Safety, antigenicity, and efficacy of a recombinant coccidioidomycosis vaccine in cynomolgus macaques (Macaca fascicularis). Ann N Y Acad Sci 1111: 290-300.
95. Herr RA, Hung CY, Cole GT (2007) Evaluation of two homologous proline-rich proteins of Coccidioides posadasii as candidate vaccines against coccidioidomycosis. Infect Immun 75: 5777-5787.

96. Reis BS, Fernandes VC, Martins EM, Serakides R, Goes AM (2008) Protective immunity induced by $\mathrm{rPb} 27$ of Paracoccidioides brasiliensis. Vaccine 26: 5461-5469. 